\title{
Genetic Diversity of the Endemic Xantus' Hummingbird Using 16 Novel Polymorphic Microsatellite Loci, and Their Cross Amplification between Six Related Species
}

\author{
Cristina González-Rubio Sanvicente1 ${ }^{1}$, Ricardo Rodríguez-Estrella², \\ Oscar Adrián Lozano-Garza1, Francisco J. García-De-León ${ }^{1 *}$ \\ ${ }^{1}$ Laboratorio de Genética para la Conservación, Centro de Investigaciones Biológicas del Noroeste, La Paz, \\ Mexico \\ ${ }^{2}$ Laboratorio de Análisis Espacial, Ecología y Conservación, Centro de Investigaciones Biológicas del Noroeste, \\ La Paz, Mexico \\ Email:cgrs83@gmail.com, estrella@cibnor.mx,adrian.lozano@cambiental.mx, fgarciadl@cibnor.mx
}

Received 11 February 2016; accepted 21 March 2016; published 24 March 2016

Copyright (C) 2016 by authors and Scientific Research Publishing Inc.

This work is licensed under the Creative Commons Attribution International License (CC BY). http://creativecommons.org/licenses/by/4.0/

(c) (i) Open Access

\begin{abstract}
A set of 16 microsatellite loci was developed and characterized for the Xantus' hummingbird (Hylocharis xantusii) by using 454 next-generation sequencing. Twenty-five $H$. xantusii samples from one population were genotyped; all loci were polymorphic, with the number of alleles ranging from three to ten. The mean observed heterozygosity was 0.681 for all loci. No significant linkage disequilibrium was detected, but five loci (Hxan05, 06, 09, 13 and 14) showed deviation from Hardy-Weinberg equilibrium. These microsatellite loci are the first to be characterized for $\mathrm{H}$. xantusii. A moderate to high level of cross-species amplification was observed across the six hummingbird species $(31 \%-87.5 \%)$, with the best cross amplification results observed in the closest related species (H. leucotis, Cynanthus latirostris, Calypte costae). The availability of these molecular tools allows assessing questions integrating population genetics, ecology, conservation, and evolutionary history for $\boldsymbol{H}$. xantusii and for other phyogenetically related species.
\end{abstract}

\section{Keywords}

Baja California Peninsula, Hylocharis xantusii, Microsatellites, Pyrosequencing, Cross-Species Amplification

\footnotetext{
${ }^{*}$ Corresponding author.
} 


\section{Introduction}

Endemic species with a narrow distribution and specific habitat requirements are usually vulnerable to ecological disturbances and environmental changes (e.g. deforestation, introduced diseases, competition and predation pressures) [1]. Therefore, it is fundamental to develop long-term conservation plans of these kinds of species based on habitat and genetic information, such as genetic diversity [2]. Microsatellites are one of the most popular genetic markers for a wide range of applications in population genetics, conservation biology, and evolutionary biology. Loci developed using genomic sequencing for microsatellite markers design offer the opportunity to obtain enough genetic information for species where genetic data are limited [3].

The Xantus' hummingbird Hylocharis xantusii (Lawrence 1860) is endemic to central and southern Baja California Peninsula (BCP); limited information is available regarding its biology and ecology [4], but it has been observed that its distribution is discontinuous, having four genetic populations mainly associated to oases [5]. This species can be found in oak-pine and tropical deciduous forests, oases, canyons and streams; often near fresh water [4] [6] [7]. The Baja California Peninsula is one of the longest (1800 km long) and most isolated peninsulas in the world, and it comprehends a heterogeneous array of landscapes and habitats. In this territory, although hummingbird populations exist along environmental gradients, individuals are likely to be limited by particular local conditions [6] [7]. As a consequence, size and genetic diversity of populations could be affected subsequently reducing individuals' fitness. Therefore, understanding the processes of biological diversification and genetic variation for endemic or restricted species like $H$. xantusii is vital to identify evolutionary significant areas for conservation in a scenario of accelerated increase of environmental disturbances (e.g. habitat fragmentation due human activity) [8].

H. xantusii belongs to the family Trochilidae which has the highest specialization rate among nectarivorous birds in the world; it is a medium-sized hummingbird with a remarkably sexual dimorphism, with males having orange bill and colorful plumage [5]. Phylogenetic relationships within the family have recently begun to be studied through molecular data. Most of these studies have focused on the higher classification level (i.e. within the family), but given their levels of variability and for a better comprehension of the evolution of hummingbird species, it is necessary to analyze the relationships among and within genera using a similar approach [9]. In this case, we particularly focus on the only endemic hummingbird species of the BCP, the Xantus' hummingbird.

We developed and characterized 16 polymorphic microsatellite loci for $H$. xantusii using 454 pyrosequencing methods. We isolated the loci to be used as a tool in estimating genetic diversity, and for its potential use in further genetic estimations such as gene flow and the measure of population structure across entire distribution of the Xantus' hummingbird. Additionally, we tested the transferability and level of polymorphism of the genetic markers developed in six related species, in order to confirm the utility of the markers for further broader comparative analysis.

\section{Material and Methods}

\subsection{Sample Collection and DNA Preparation}

A sample of 25 individuals of $H$. xantusii were collected from three localities; Santiago (2348'24"N, 109 $\left.72^{\prime} 30^{\prime \prime} \mathrm{W}\right)$, Sierra de la Laguna $\left(26^{\circ} 04^{\prime} 38^{\prime \prime} \mathrm{N}, 110^{\circ} 00^{\prime} 68^{\prime \prime} \mathrm{W}\right)$ and San Dionisio $\left(23^{\circ} 55^{\prime} 86^{\prime \prime} \mathrm{N}, 109^{\circ} 86^{\prime} 55^{\prime \prime} \mathrm{W}\right)$, for population characterization. These locations correspond to one genetic population characterized by mitochondrial genes [5]. Additionally, samples from six related hummingbird species (Figure 1) were obtained in the field: nine individuals of Calypte costae from four localities in the BCP (Santa Gertrudis $28^{\circ} 05^{\prime} 01^{\prime \prime N}, 113^{\circ} 08^{\prime} 65^{\prime \prime} \mathrm{W}$; San Ignacio

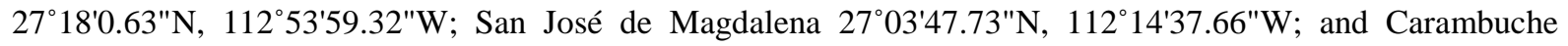
$26^{\circ} 12^{\prime} 53.50^{\prime \prime} \mathrm{N}, 112^{\circ} 11^{\prime} 35.40^{\prime \prime} \mathrm{W}$ ); five individuals of Archilochus alexandri from two localities in the BCP (San Borja 28 $44^{\prime} 36.5^{\prime \prime} \mathrm{N}, 113^{\circ} 45^{\prime} 13.7^{\prime \prime} \mathrm{W}$; and San Isidro $\left.28^{\circ} 97^{\prime} 58^{\prime \prime} \mathrm{N}, 112^{\circ} 03^{\prime} 33^{\prime \prime} \mathrm{W}\right)$; 10 individuals of $\mathrm{H}$. leucotis and six individuals for Cynanthus latirostris were obtained from El Fuerte, Sinaloa (26 25'19.3"N, $\left.108^{\circ} 37^{\prime} 13.1^{\prime \prime} \mathrm{W}\right)$ and Álamos, Sonora (27 $\left.00^{\prime} 53.2^{\prime \prime} \mathrm{N}, 108^{\circ} 56^{\prime} 51.2^{\prime \prime} \mathrm{W}\right)$; five individuals of Amazilia rutila and five specimens of $A$. candida from Agua Blanca, Sinaloa (24 $\left.53^{\prime} 28.4^{\prime \prime N}, 107^{\circ} 19^{\prime} 28.8^{\prime \prime W}\right)$. Birds were captured with mist nets and blood samples were collected from the tarsus before birds were released. It was verified that no injuries were made to birds during blood sampling.

Genomic DNA was extracted using a salt protocol [10]. A sample of 50 ng of RNA-free, high quality DNA from an individual of $H$. xantusii collected at Santiago, was used for shotgun sequencing by using a 454 

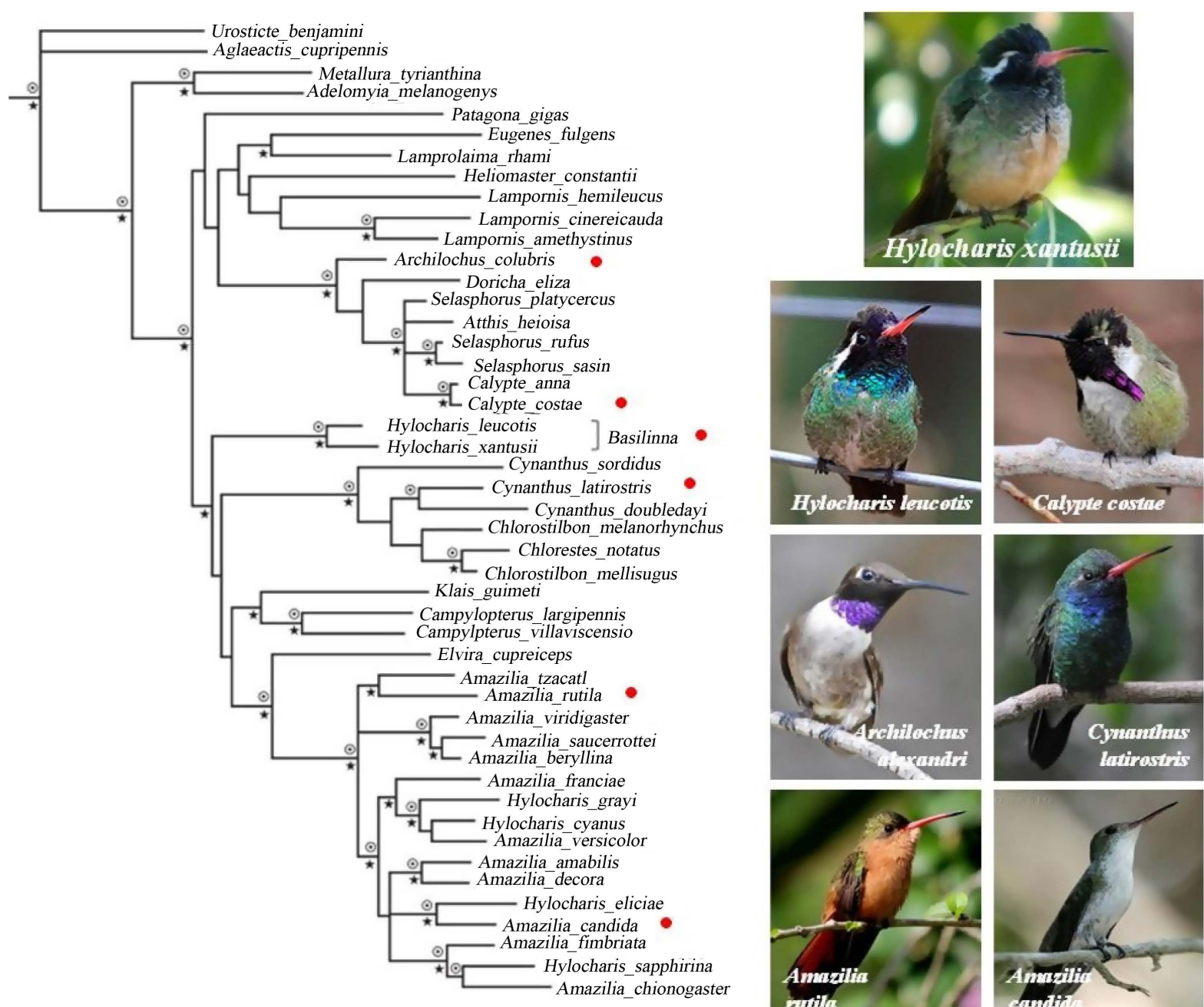

Figure 1. Phylogenetic relationships among hummingbird species adding the microsatellite cross amplification from this work (modified from Hernández-Baños et al. [9]). Red dots indicate the phylogenetic position of each species. Picture of $H$. xantusii was taken by CGRS; the rest of the species pictures were taken from the database of Comisión Nacional para el Conocimiento y Uso de la Biodiversidad (CONABIO; http://naturalista.conabio.gob.mx/, http://bios.conabio.gob.mx/, http://bdi.conabio.gob.mx/).

GS-FLX Titanium instrument (Roche Applied Sciences, Indianapolis, Indiana, USA) at the UCSC Genome Sequencing Center (Santa Cruz, California, USA).

\subsection{Microsatellite Loci Identification and Primer Design}

All 454 reads were converted to primer design following the methodologies of Abdelkrim et al. [3] and Lozano Garza et al. [11]. In short, flowgrams were converted to fasta files for the reading of all the sequences; then, Msatcommander [12] was used to identify sequences that included perfect microsatellites with 2 - 6 bp repeat units, and had at least five repeats for tetra-nucleotides. From the set of putative loci, primers were designed using Primer 3 software embedded in QDD [13], using the following specifications: 1) melting temperatures $50^{\circ} \mathrm{C}-70^{\circ} \mathrm{C}$ with a maximum $2^{\circ} \mathrm{C}$ difference between paired primers, 2) PCR product between 90 and $320 \mathrm{bp}, 3$ ) GC content $>40 \%$, 4) primers length between 17 and 27 nucleotides, and 5) the primers self-complementarities and complement between them, satisfying the quality criteria used as default parameters. Fifty five primer pairs were chosen for PCR amplification screening and polymorphism test. The loci names were designated with the prefix "Hxan" and a consecutive number (1 - 55). Polymorphic forward primer sequences were labeled with fluorescent dyes (Applied Biosystems, Foster City, California, USA) for automated detection (see below). 


\subsection{PCR Procedures and Data Analysis}

PCR reactions were performed in a $10 \mu \mathrm{L}$ volume containing about $40 \mathrm{ng}$ of DNA, $1 \times$ PCR buffer $(20 \mathrm{mM}$ Tris-HCl, pH 8.4, $50 \mathrm{mM} \mathrm{KCl}$ ), $0.2 \mathrm{mM}$ of each dNTP, $0.4 \mu \mathrm{M}$ of each primer, $1.5-2.5 \mu \mathrm{M} \mathrm{MgCl}_{2}$, and $0.5 \mathrm{U}$ Taq DNA polymerase (Invitrogen, Carlsbad, California, USA). The temperature profiles included an initial denaturation at $94^{\circ} \mathrm{C}$ for $5 \mathrm{~min}$, followed by 30 cycles at $94^{\circ} \mathrm{C}$ for $1 \mathrm{~min}$ each and $30 \mathrm{~s}$ at the locus-specific annealing temperature (Table 1), and a final extension at $72^{\circ} \mathrm{C}$ for $5 \mathrm{~min}$. Amplification products were visualized in ABI 310-3730 PRISM ${ }^{\circledR}$ (Life Technologies, Carlsbad, California, USA), using LIZ600 as size standard (Applied Biosystems).

Allele assignation was automated with GeneMapper 4.1 (Applied Biosystems). The minimum peak height acceptance was set to 100 Relative Fluorescence Units (RFU), and the minimum height ratio between peaks for heterozygotes to one third. All peaks assigned were manually checked for allele shape.

Table 1. Summary data for 16 polymorphic microsatellite loci developed for Hylocharis xantusii. Includes the GenBank accession number, primer sequences, repeat motifs, annealing temperature (Ta), optimized magnesium chloride concentration $\left(\mathrm{MgCl}_{2}\right)$, allele size range, number of alleles observed $\left(\mathrm{N}_{\mathrm{A}}\right)$, observed and expected heterozygosities $\left(\mathrm{H}_{\mathrm{O}}\right.$ and $\mathrm{H}_{\mathrm{E}}$ respectively), and statistical significance of deviation from Hardy-Weinberg equilibrium $\left(\mathrm{P}_{\mathrm{HW}}\right)$.

\begin{tabular}{|c|c|c|c|c|c|c|c|c|c|c|}
\hline $\begin{array}{l}\text { Accession } \\
\text { no. }\end{array}$ & Locus & Primer pair sequence (5’-3’) & $\begin{array}{l}\text { Repeat } \\
\text { motif }\end{array}$ & $\begin{array}{c}\text { Ta } \\
\left({ }^{\circ} \mathbf{C}\right)\end{array}$ & $\begin{array}{c}\mathrm{MgCl}_{2} \\
{[\mathrm{mM}]}\end{array}$ & $\begin{array}{l}\text { Size range } \\
\text { (bp) }\end{array}$ & $\mathbf{N}_{\mathbf{A}}$ & $\mathbf{H}_{\mathbf{O}}$ & $\mathbf{H}_{\mathbf{E}}$ & $\mathbf{P}_{\mathrm{HW}}$ \\
\hline KU681466 & Hxan01 & $\begin{array}{l}\text { F: TTAAGCACCCCAGTCAAAGG } \\
\text { R: CCCAATGTCAGGGATTTTGT }\end{array}$ & $(\mathrm{AAAT})_{6}$ & 65 & 2.5 & $220-226$ & 4 & 0.625 & 0.666 & \\
\hline KU681467 & Hxan02 & $\begin{array}{l}\text { F: AAATCTTCATTTTGCATGCATTT } \\
\text { R: CTTTGATGCCATCCCAATCT }\end{array}$ & $(\mathrm{AAAC})_{7}$ & 65 & 2.5 & $120-156$ & 3 & 0.542 & 0.426 & \\
\hline KU681468 & Hxan03 & $\begin{array}{l}\text { F: GGCAGCCCAAATTGCTACTA } \\
\text { R: TGTGCTGTTCTCCATCCATC }\end{array}$ & $(\text { TGGA })_{22}$ & 65 & 2.5 & $117-167$ & 7 & 0.792 & 0.744 & \\
\hline KU681469 & Hxan04 & $\begin{array}{l}\text { F: CACATTTGTGCTCTGATGGC } \\
\text { R: GAGACAACTCAGGCATTCCC }\end{array}$ & $(\mathrm{ATTT})_{6}$ & 70 & 2.5 & $169-201$ & 7 & 0.667 & 0.742 & \\
\hline KU681470 & Hxan05 & $\begin{array}{l}\text { F: CAATGTGCAGTCTCAGGGAA } \\
\text { R: CTCCTGTGCTCAAGGGAGAG }\end{array}$ & $(\text { TGGA })_{5}$ & 70 & 2.5 & $135-178$ & 5 & 0.292 & 0.490 & *** \\
\hline KU681471 & Hxan06 & $\begin{array}{l}\text { F: GCCAGTGCAGAAGATGGACC } \\
\text { R: AGCCTGGCTCCTCCGTAGTC }\end{array}$ & $(\mathrm{CATC})_{5}$ & 60 & 2.5 & $132-172$ & 5 & 0.417 & 0.661 & $* * *$ \\
\hline KU681472 & Hxan07 & $\begin{array}{l}\text { F: TTCTCACAATGGGAGCCCTG } \\
\text { R: GGGAGCAAGTGCATTCAGGA }\end{array}$ & $(\mathrm{ACAG})_{5}$ & 70 & 2 & $88-156$ & 10 & 0.792 & 0.853 & \\
\hline KU681473 & Hxan09 & $\begin{array}{c}\text { F: CTCTGTGATCAGGCTTTTCCA } \\
\text { R: AGTGTAGATATAGATGATAGAGACAGA }\end{array}$ & $(\mathrm{TCTA})_{17}$ & 66 & 2.5 & $141-193$ & 10 & 0.810 & 0.848 & $* *$ \\
\hline KU681474 & Hxan11 & $\begin{array}{l}\text { F: TGGGTTTTCAGTCTGATGGA } \\
\text { R: TCTGGGGATTCACATAAGTA }\end{array}$ & $(\mathrm{CATC})_{15}$ & 60 & 1.5 & $124-140$ & 4 & 0.667 & 0.510 & \\
\hline KU681475 & Hxan12 & $\begin{array}{l}\text { F: AATGGATGCATGGCTGGTG } \\
\text { R: GCCTATGCATTCTCCCAGGC }\end{array}$ & $(\mathrm{ATGG})_{11}$ & 60 & 1.5 & $110-134$ & 6 & 0.917 & 0.674 & \\
\hline KU681476 & Hxan13 & $\begin{array}{l}\text { F: CCACTCAGGAAGGCCAAAGA } \\
\text { R: GGATGTACCACCAGCTTGCC }\end{array}$ & $(\text { TGGA })_{13}$ & 70 & 2 & $149-185$ & 8 & 0.500 & 0.646 & $* * *$ \\
\hline KU681477 & Hxan14 & $\begin{array}{l}\text { F: CATCACCCTAACAAACCCC } \\
\text { R: GCACAGGGTGGGAGTAGTGC }\end{array}$ & $(\mathrm{ATCC})_{14}$ & 70 & 2.5 & $99-176$ & 8 & 0.522 & 0.831 & $* * *$ \\
\hline KU681478 & Hxan15 & $\begin{array}{l}\text { F: GATGTTTCAGGGGAAGTCCG } \\
\text { R: TAAATGAGAGCTGCCCCGTG }\end{array}$ & $(\mathrm{ATCC})_{19}$ & 66 & 2.5 & $78-132$ & 9 & 0.739 & 0.820 & \\
\hline KU681479 & Hxan16 & $\begin{array}{l}\text { F: GTCACTGCCCAGCAACCACT } \\
\text { R: TCAGGGGAGAAGCAGACCAC }\end{array}$ & $(\mathrm{CAGA})_{10}$ & 68 & 2.5 & $73-125$ & 10 & 1.000 & 0.810 & \\
\hline KU681480 & Hxan17 & $\begin{array}{l}\text { F: TCAGGGGAGAAGCAGACCAC } \\
\text { R: ACTGCCCAGCAACCCACTC }\end{array}$ & $(\mathrm{TCTG})_{10}$ & 66 & 2.5 & $94-154$ & 10 & 0.875 & 0.861 & \\
\hline KU681481 & Hxan18 & $\begin{array}{l}\text { F: GCTGGTACCGGAGGTTGATG } \\
\text { R: TGGATGAATGACGGAGGAGG }\end{array}$ & $(\mathrm{CATT})_{13}$ & 68 & 2.5 & $133-169$ & 5 & 0.739 & 0.681 & \\
\hline
\end{tabular}

${ }^{* *} \mathrm{P}<0.01,{ }^{* * *} \mathrm{P}<0.001$ = significance of deviation from Hardy-Weinberg equilibrium after 1000 permutation. 
Presence and frequency of null alleles were assessed using FreeNA software [14]. Number of alleles per locus (Na), expected and observed heterozygosities $\left(\mathrm{H}_{\mathrm{E}}\right.$ and $\mathrm{H}_{\mathrm{O}}$, respectively) were obtained using GenALEx 6.5 [15]. Deviations from Hardy-Weinberg equilibrium, and linkage disequilibrium between markers were tested using default parameters in GENEPOP 4.2 [16].

\section{Results and Discussion}

\subsection{Identification of Polymorphic Microsatellites Loci}

The 454 pyrosequence reaction resulted in 143,625 reads, from which only 815 reads contained a microsatellite motif and were suitable for primer design. Out of the 55 chosen loci for PCR and polymorphism screening, 10 exhibited inconsistent amplification patterns, 14 were monomorphic, and 31 were polymorphic. Within the 31 polymorphic loci, only tretra-nucleotide loci recording successfully more than $50 \%$ of the genotypes (Table 1), were selected for population characterization.

There was no previous information available for any microsatellite development technique for Hylocharis xantusii species. There are just a few hummingbird studies using microsatellite loci [17] [18], but none that had evaluated the effectiveness of microsatellites among closely related hummingbirds by cross-species amplification, or had compared against the results of other birds' species.

\subsection{Characterization of Genetic Diversity}

GenBank accession numbers, locus ID designation, primer sequences, repeat motifs, number of alleles, observed and expected heterozygosity for the 16 microsatellite loci developed for $H$. xantusii are listed in Table 1 . The number of alleles per locus ranged from 3 (locus Hxan02) to 10 (locus Hxan07, 09, 16 and 17). The null allele frequency estimates ranged from negligible, less than 0.05 (11 loci) to small, between $0.05-0.17$ (locus Hxan04-06, 11, 12), according to the ranges proposed in Chapuis and Estoup [14]. Observed heterozygosity among loci ranged from 0.29 (locus Hxan05) to 0.99 (locus Hxan16), with a mean of 0.68; expected heterozygosity ranged from 0.42 (locus Hxan02) to 0.86 (locus Hxan17), with a mean of 0.7. No significant linkage disequilibrium was detected, but five loci (Hxan05, 06, 09, 13, and 14) showed significant deviations from HardyWeinberg expectations, after Bonferroni correction.

\subsection{Cross-Species Amplification and Polymorphic Levels}

Of the six phylogenetically related hummingbird species that were used in this work to validate the effectiveness of the novel microsatellites (Table 2), only three showed high levels of polymorphism regarding the number of amplified loci: Hylocharis leucotis (87.5\%), Calypte costae (87.5\%), and Cynanthus latirostris (75\%). The null allele frequency estimates were similar between them, ranging from negligible (less than 0.05$)$ to larger $(>0.2)$ (according to the ranges proposed by Chapuis and Estoup [14]). The number of alleles per locus ranged from 2 to 8; observed and expected heterozygosity were lower than $H$. xantusii, and although no significant linkage disequilibrium was detected, some loci showed statistically significant deviations from Hardy-Weinberg equilibrium, nine for $H$. leucotis, five for C. costae, and only one for C. latirostris.

C. costae is the only co-distributed species with H. xantusii. While H. leucotis is the only sister species of Xantus' hummingbird, but with a continental distribution. C. latirostris is the most phylogenetic related species to H. xantusii and H. leucotis [9] (Figure 1). These could be the reason for the high polymorphism observed in these species. It has been observed that related species or genetically less distant, have a better microsatellite performance, which means a higher proportion of amplified loci through cross-species amplification [19].

In the other three species (Archilochus alexandri, Amazilia candida, and A. rutila) the number of alleles per locus (two for most of the loci), and the polymorphism values (56\%, 44\% and 31\% respectively), were low compared to other cross-species amplification assays for birds groups [19]. Thus, the possibility of low levels of polymorphism observed being an artifact due to small sample sizes, cannot be discarded (Table 3).

\subsection{Comparison of Polymorphic Levels between Birds' Species Using Microsatellite Loci}

Although it has been observed that avian genomes show a low frequency of microsatellites compared with other organisms [3], many studies have shown that birds have considerable polymorphism to determine measures of 
Table 2. Genetic diversity and polymorphism levels using novel microsatellite loci by cross-species amplification. It includes the number and percentage of polymorphism (Polym), number of alleles observed $\left(\mathrm{N}_{\mathrm{A}}\right)$, and observed and expected heterozygosities $\left(\mathrm{H}_{\mathrm{O}}\right.$ and $\mathrm{H}_{\mathrm{E}}$ respectively).

\begin{tabular}{|c|c|c|c|c|c|c|c|c|c|c|c|c|c|c|c|c|c|c|c|}
\hline \multirow[t]{2}{*}{ Locus } & \multirow[t]{2}{*}{$\begin{array}{c}\boldsymbol{H} . \\
\text { xantusii } \\
\mathrm{N}_{\mathrm{A}}\end{array}$} & \multicolumn{3}{|c|}{$\begin{array}{c}\text { H. leucotis } \\
(\mathrm{n}=10) \\
\text { Polym = 14 } \\
(87.5 \%)\end{array}$} & \multicolumn{3}{|c|}{$\begin{array}{c}\text { C. costae } \\
(\mathrm{n}=9) \\
\text { Polym = } 14 \\
(87.5 \%)\end{array}$} & \multicolumn{3}{|c|}{$\begin{array}{c}\begin{array}{c}\text { C. latirostris } \\
(\mathrm{n}=6)\end{array} \\
\text { Polym = } 12 \\
(75 \%)\end{array}$} & \multicolumn{3}{|c|}{$\begin{array}{l}\begin{array}{c}\text { A. alexandri } \\
(\mathrm{n}=5)\end{array} \\
\text { Polym }=9 \\
(56.3 \%)\end{array}$} & \multicolumn{3}{|c|}{$\begin{array}{l}\text { A. candida } \\
(\mathrm{n}=5) \\
\text { Polym }=7 \\
(43.7 \%)\end{array}$} & \multicolumn{3}{|c|}{$\begin{array}{c}\begin{array}{c}\text { A. rutila } \\
(\mathrm{n}=5)\end{array} \\
\text { Polym = } 5 \\
(31.3 \%)\end{array}$} \\
\hline & & $\mathbf{N}_{\mathrm{A}}$ & $\mathbf{H}_{\mathbf{O}}$ & $\mathbf{H}_{\mathrm{E}}$ & $\mathbf{N}_{\mathrm{A}}$ & $\mathbf{H}_{\mathbf{O}}$ & $\mathbf{H}_{\mathrm{E}}$ & $\mathbf{N}_{\mathrm{A}}$ & $\mathbf{H}_{\mathbf{O}}$ & $\mathbf{H}_{\mathrm{E}}$ & $\mathbf{N}_{\mathrm{A}}$ & $\mathbf{H}_{\mathbf{O}}$ & $\mathbf{H}_{\mathrm{E}}$ & $\mathbf{N}_{\mathrm{A}}$ & $\mathbf{H}_{\mathbf{O}}$ & $\mathbf{H}_{\mathrm{E}}$ & $\mathbf{N}_{\mathrm{A}}$ & $\mathbf{H}_{\mathbf{O}}$ & $\mathbf{H}_{\mathrm{E}}$ \\
\hline Hxan01 & 4 & 3 & 0.200 & $0.54^{* *}$ & \multicolumn{3}{|c|}{ Monomorphic } & 3 & 0.167 & 0.403 & 2 & 0.250 & 0.469 & \multicolumn{3}{|c|}{ Monomorphic } & \multicolumn{3}{|c|}{ Monomorphic } \\
\hline Hxan02 & 3 & 2 & 0.400 & 0.320 & 4 & 1.000 & 0.735 & 2 & 0.167 & 0.153 & \multicolumn{3}{|c|}{ Monomorphic } & 2 & 1.000 & 0.500 & \multicolumn{3}{|c|}{ Monomorphic } \\
\hline Hxan03 & 7 & 2 & 0.400 & 0.320 & 3 & 0.444 & 0.593 & 5 & 0.667 & 0.611 & 2 & 0.250 & 0.219 & 2 & 0.500 & 0.375 & 2 & 1.000 & 0.500 \\
\hline Hxan04 & 7 & 2 & 0.300 & 0.255 & 2 & 0.444 & 0.346 & & onomor & rphic & 2 & 0.750 & 0.469 & Mo & nomorp & phic & Mo & nomorp & bhic \\
\hline Hxan05 & 5 & 2 & 0.300 & 0.495 & 2 & 0.222 & 0.444 & & onomor & rphic & 2 & 0.250 & 0.469 & Mo & nomorp & phic & Mo & nomorp & hic \\
\hline Hxan06 & 5 & 2 & 0.000 & $0.48^{* *}$ & 3 & 0.556 & $0.66^{* *}$ & 2 & 0.500 & 0.375 & \multicolumn{3}{|c|}{ Monomorphic } & \multicolumn{3}{|c|}{ Monomorphic } & \multicolumn{3}{|c|}{ Monomorphic } \\
\hline Hxan07 & 10 & 5 & 0.500 & $0.715^{* *}$ & 4 & 0.667 & $0.66^{*}$ & 3 & 0.667 & 0.486 & 2 & 1.000 & $0.5^{*}$ & 3 & 1.000 & 0.625 & 2 & 0.500 & 0.375 \\
\hline Hxan09 & 10 & 5 & 0.800 & 0.635 & 2 & 0.667 & 0.444 & 2 & 0.333 & 0.278 & \multicolumn{3}{|c|}{ Monomorphic } & 2 & 1.000 & 0.500 & \multicolumn{3}{|c|}{ Monomorphic } \\
\hline Hxan11 & 4 & 3 & 0.400 & $0.62^{* *}$ & 4 & 0.444 & $0.691^{* *}$ & 3 & 0.500 & $0.625^{* *}$ & - & - & - & - & - & - & - & - & - \\
\hline Hxan12 & 6 & - & - & - & - & - & - & - & - & - & - & - & - & - & - & - & - & - & - \\
\hline Hxan13 & 8 & - & - & - & 2 & 0.444 & 0.494 & - & - & - & - & - & - & - & - & - & - & - & - \\
\hline Hxan14 & 8 & 6 & 0.400 & $0.73^{*}$ & 6 & 0.556 & 0.778 & 4 & 0.833 & 0.736 & 3 & 0.500 & $0.625^{*}$ & 2 & 1.000 & 0.500 & 2 & 1.000 & 0.500 \\
\hline Hxan15 & 9 & 6 & 0.333 & $0.833^{*}$ & 4 & 0.444 & 0.568 & 5 & 0.333 & 0.681 & 2 & 0.500 & 0.375 & \multicolumn{3}{|c|}{ Monomorphic } & 2 & 0.000 & 0.500 \\
\hline Hxan16 & 10 & 3 & 0.000 & $0.656^{* *}$ & 5 & 0.286 & $0.775^{* *}$ & 5 & 0.600 & 0.720 & 2 & 0.250 & 0.219 & 4 & 1.000 & 0.750 & - & - & - \\
\hline Hxan17 & 10 & 8 & 0.500 & $0.8^{*}$ & 2 & 0.500 & 0.375 & 8 & 0.667 & 0.778 & Mo & nomorp & phic & - & - & - & 2 & 1.000 & 0.500 \\
\hline Hxan18 & 5 & 3 & 0.300 & $0.605^{* *}$ & 4 & 0.222 & $0.561^{* *}$ & 2 & 0.667 & 0.444 & 3 & 0.500 & 0.531 & 3 & 0.500 & 0.625 & \multicolumn{3}{|c|}{ Monomorphic } \\
\hline Mean & 6.94 & 3.71 & 0.35 & 0.41 & 3.36 & 0.49 & 0.53 & 3.67 & 0.51 & 0.51 & 2.22 & 0.47 & 0.39 & 2.57 & 0.86 & 0.55 & 2.00 & 0.70 & 0.48 \\
\hline
\end{tabular}

genetic differentiation (see Table 3). We compared levels of polymorphism between different birds groups in order to establish if our microsatellite loci of de novo isolation and characterization have enough resolution to address questions about the processes driving population divergence and speciation (e.g. gene flow) and about the evolutionary biology of the Xantus' hummingbird (Table 3).

For example, in hummingbird species like the wedge-tailed sabrewing (Campylopterus curvipennis), which has a complex evolutionary history [17] [18], the analyses of ten microsatellite loci genotyped within 160 individuals (1 to 27 individuals per locality), were enough to evidence the presence of three lineages with no contemporary gene flow.

In general, all genetic studies based on the development of novel microsatellite have shown the effectiveness in the cross-species amplification, regardless of the group, geographic distribution and life history [2] [3] [20][27]; even in extreme cases for endemic species like the Japanese wood pigeon (Columba janthina), with a high risk of extinction due to its small population size and low genetic diversity [3], seven microsatellites developed for the species and the cross-subspecies amplification, revealed differences in allele frequencies between populations. This showed that despite the low number of alleles observed, the genetic information gathered was sufficient to determine what population faces the major extinction risk.

\section{Conclusion}

It was found that the isolation of microsatellite loci for $H$. xantusii using next generation sequencing was successful due to the number of polymorphic loci and the number of alleles per locus obtained. These markers are 
Table 3. Comparison between the number of microsatellite loci developed and the number of alleles per locus in multiple birds species. Includes the sample size (n) and observed and expected heterozygosities $\left(\mathrm{H}_{\mathrm{O}}\right.$ and $\mathrm{H}_{\mathrm{E}}$ respectively).

\begin{tabular}{|c|c|c|c|c|c|c|c|}
\hline Species & Distribution & $\mathbf{n}$ & loci & $\begin{array}{l}\text { Alleles/ } \\
\text { locus }\end{array}$ & $\mathbf{H}_{\mathbf{O}}$ & $\mathbf{H}_{\mathrm{E}}$ & Reference \\
\hline Hylocharis xantusii & Endemic of the BCP & 25 & 16 & $3-10$ & $0.29-0.9$ & $0.42-0.86$ & This work \\
\hline Hylocharis leucotis & $\begin{array}{l}\text { Southwestern US } \\
\text { to Nicaragua }\end{array}$ & 10 & 14 & $2-8$ & $0.2-0.8$ & $0.25-0.83$ & This work \\
\hline Calyptecostae & Western US and Mexico & 9 & 14 & $2-6$ & $0.22-0.9$ & $0.34-0.77$ & This work \\
\hline Campylopterus curvipennis & $\begin{array}{l}\text { Mexico, Belize, } \\
\text { Guatemala, Honduras }\end{array}$ & 160 & 10 & $4-20$ & $0.18-0.65$ & $0.30-0.64$ & [17] [18] \\
\hline Hymenolaimus malacorhynchos & $\begin{array}{l}\text { New Zealand's } \\
\text { endangered }\end{array}$ & 1 & 13 & $2-4$ & - & - & [3] \\
\hline Garrulax elliotii & $\begin{array}{c}\text { Endemic of eastern } \\
\text { Himalayas }\end{array}$ & 80 & 10 & $2-9$ & $0.0-0.86$ & $0.07-1$ & [20] \\
\hline Columba janthina janthina & Endemic islands east Asia & 15 & 7 & $1-7$ & $0.0-0.67$ & $0.0-0.64$ & [2] \\
\hline Columba janthina nitens & Endemic islands east Asia & 25 & 2 & $1-3$ & $0.0-0.08$ & $0.0-0.08$ & [2] \\
\hline Pomatostomus ruficeps & $\begin{array}{c}\text { Endemic to Australia and } \\
\text { New Guinea }\end{array}$ & 1197 & 9 & $11-21$ & - & $0.74-0.91$ & {$[21]$} \\
\hline Laruss aundersi & Global and vulnerable & 30 & 9 & $4-15$ & $0.58-0.89$ & $0.58-0.9$ & {$[22]$} \\
\hline Varieties of geese & Native of Poland & 160 & 14 & $3-19$ & $0.45-0.55$ & $0.38-0.51$ & [23] \\
\hline Breeds of chickens & Egypt traces & 251 & 29 & $3-20$ & $0.22-0.84$ & $0.32-0.88$ & {$[24]$} \\
\hline Columba livia var. domestica & Europe, Asia, Africa & 22 & 18 & $2-18$ & $0.23-0.91$ & $0.35-0.94$ & [25] \\
\hline Rhynchotus rufescens & South America & 24 & 6 & $2-12$ & $0.27-0.82$ & $0.27-0.86$ & [26] \\
\hline Ciconia boyciana & $\begin{array}{l}\text { North China to southeast } \\
\text { of Russia }\end{array}$ & 23 & 11 & $2-8$ & $0.0-0.86$ & $0.22-0.85$ & {$[27]$} \\
\hline
\end{tabular}

- = no data available.

potentially useful for multiple hummingbird species. Moderate to high levels of cross-species amplification were observed across the six hummingbird species $(31 \%-87.5 \%)$, with the best results obtained in closely related species, also showing higher levels of polymorphism $\left(\mathrm{N}_{\mathrm{A}}\right)$. The availability of these molecular tools enables to address questions integrating population genetics, ecology, conservation, and evolutionary history for $\mathrm{H}$. xantusii and for other phylogenetically related species.

\section{Acknowledgements}

We thank Franco Cota and Abelino Cota for field assistance, and Mabilia Urquidi-Gaume for English edition. Carlos Garza from NOAA who helped with the next generation sequencing at UCSC Genome Sequencing Center (Santa Cruz, CA). The Mexican government issued the permit (SGPA/DGVS/10182/11 and 06983/13) for the individuals collected in this research. CGRS acknowledges CONACyT for a student fellowship (No. 8492). Funding was provided by the Consejo Nacional de Ciencia y Tecnología, Mexico granted to FJGL (CONACyT project CB-2008-01-106925), and to RRE (CONACyT project155956).

\section{References}

[1] Frankham, R., Ballou, J.D. and Briscore, D.A. (2002) Introduction to Conservation Genetics. Cambridge University Press, Cambridge. http://dx.doi.org/10.1017/CBO9780511808999

[2] Ando, H., Kaneko, S., Suzuki, H., Horikoshi, K., Takano, H., Ogawa, H. and Isagi, Y. (2011) Genetic Diversity of the Japanese Wood Pigeon, Columba janthina, Endemic to Islands of East Asia, Estimated by Newly Developed Microsatellite Markers. Zoological Science, 28, 891-896. http://dx.doi.org/10.2108/zsj.28.891

[3] Abdelkrim, J., Robertson, B., Stanton, J.A. and Gemmell, N. (2009) Fast, Cost-Effective Development of SpeciesSpecific Microsatellite Markers by Genomic Sequencing. BioTechniques, 46, 185-192. 
http://dx.doi.org/10.2144/000113084

[4] Howell, C.A. and Howell, S.N. (2000) Xantus's Hummingbird (Hylocharis xantusii). The Birds of North America Online, 14. http://dx.doi.org/10.2173/bna.554

[5] González Rubio, C., García-De-León, F.J. and Rodríguez Estrella, R. (2016) Phylogeography of Endemic Xantus’ Hummingbird (Hylocharis xantusii) Show a Different History of Vicariance in the Baja California Peninsula. Unpublished.

[6] Rodríguez-Estrella, R., Rubio, L. and Pineda, E. (1997) Los oasis como parches atractivos para lasavesterrestres residentes e invernantes. In: Arriaga, L. and Rodríguez-Estrella, R., Eds., Los Oasis de la Península de Baja California, Mexico, Centro de InvestigacionesBiológicas del Noroeste, La Paz, BCS, Mexico, 157-196.

[7] Rodríguez-Estrella, R., Blázquez, M.C. and Lobato, J.M. (2005) Avian Communities of Arroyos and Desert Oases in Baja California Sur: Implications for Conservation. In: Cartron, J.L.E., Ceballos, G. and Felger, R.S., Eds., Biodiversity and Conservation in Northern Mexico, Oxford University Press, UK, 334-353.

[8] Riddle, B.R., Hafner, D.J., Alexander, L.F. and Jaeger, J.R. (2000) Cryptic Vicariance in the Historical Assembly of a Baja California Peninsular Desert Biota. Proceedings National Academy of Sciences, 97, 14438-14443. http://dx.doi.org/10.1073/pnas.250413397

[9] Hernández Baños, B.E., Zamudio Beltrán, L.E., Eguiarte Fruns, L.E., Klicka, J. and García Moreno, J. (2014) The Basilinna Genus (Aves: Trochilidae): An Evaluation Based on Molecular Evidence and Implications for the Genus Hylocharis. Revista Mexicana de Biodiversidad, 85, 797-807. http://dx.doi.org/10.7550/rmb.35769

[10] Aljanabi, S.M. and Martínez, I. (1997) Universal and Rapid Salt-Extraction of High Quality Genomic DNA for PCRBased Techniques. Nucleic Acids Research, 25, 4692-4693. http://dx.doi.org/10.1093/nar/25.22.4692

[11] Lozano Garza, O.A., León de la Luz, J.L., Lara, S.F. and García-De-León, F.J. (2015) New Interpretations about Clonal Architecture for the Sour Pitaya (Stenocereus gummosus, Cactaceae), Arising from Microsatellite Markers of de Novo Isolation and Characterization. Open Journal of Genetics, 5, 1-11. http://dx.doi.org/10.4236/ojgen.2015.51001

[12] Faircloth, B.C. (2008) Msatcommander: Detection of Microsatellite Repeat Arrays and Automated, Locus-Specific Primer Design. Molecular Ecology Resources, 8, 92-94. http://dx.doi.org/10.1111/j.1471-8286.2007.01884.x

[13] Meglécz, E., Costedoat, C., Dubut, V., Gilles, A., Malausa, T., Pech, N. and Martin, J.-F. (2010) QDD: A UserFriendly Program to Select Microsatellite Markers and Design Primers from Large Sequencing Projects. Bioinformatics, 26, 403-404. http://dx.doi.org/10.1093/bioinformatics/btp670

[14] Chapuis, M.P. and Estoup, A. (2007) Microsatellite Null Alleles and Estimation of Population Differentiation. Molecular Biology and Evolution, 24, 621-631. http://dx.doi.org/10.1093/molbev/msl191

[15] Peakall, R. and Smouse, P.E. (2012) GenAlEx 6.5: Genetic Analysis in Excel. Population Genetic Software for Teaching and Research-An Update. Bioinformatics, 28, 2537-2539. http://dx.doi.org/10.1093/bioinformatics/bts460

[16] Rousset, F. (2008) GENEPOP’007: A Complete Re-Implementation of the Genepop Software for Windows and Linux. Molecular Ecology Resources, 8, 103-106. http://dx.doi.org/10.1111/j.1471-8286.2007.01931.x

[17] González, C., Ornelas, J.F. and Gutiérrez Rodríguez, C. (2011) Selection and Geographic Isolation Influence Hummingbird Speciation: Genetic, Acoustic and Morphological Divergence in the Wedge-Tailed Sabrewing (Campylopterus curvipennis). BMC Evolutionary Biology, 11, 38. http://dx.doi.org/10.1186/1471-2148-11-38

[18] González, C. and Ornelas, J.F. (2014) Acoustic Divergence with Gene Flow in a Lekking Hummingbird with Complex Songs. PLOS ONE, 9, e109241. http://dx.doi.org/10.1371/journal.pone.0109241

[19] Mukesh Javed, R., Gaur, U., Jianlin, H. and Sathyakumar, S. (2011) Cross-Species Applicability of Chicken Microsatellite Markers for Investigation of Genetic Diversity in Indian Duck (Anasplatyrhynchos) Populations. African Journal of Biotechnology, 10, 17623-17631.

[20] Qu, Y., Luo, X., Zhang, R., Song, G., Zou, F. and Lei, F. (2011) Lineage Diversification and Historical Demography of a Montane Bird Garrulaxelliotii-Implications for the Pleistocene Evolutionary History of the Eastern Himalayas. BMC Evolutionary Biology, 11, 174. http://dx.doi.org/10.1186/1471-2148-11-174

[21] Rollins, L.A., Browning, L.E., Holleley, C.E., Sabage, J.L., Russell, A.F. and Griffith, S.C. (2012) Building Genetic Networks Using Relatedness Information: A Novel Approach for the Estimation of Dispersal and Characterization of Group Structure in Social Animals. Molecular Ecology, 21, 1727-1740. http://dx.doi.org/10.1111/j.1365-294X.2012.05492.x

[22] Jiang, H.X., Ren, S.L., Hou, Y.Q., Yang, M. and Wu, X.B. (2011) Isolation and Characterization of Tetranucleotide Repeat Polymorphic Microsatellite Loci in Larussaundersi (Aves, Laridae). Genetic Molecular Resources, 10, 20342037. http://dx.doi.org/10.4238/vol10-3gmr1164

[23] Parada, R., Ksiazkiewicz, J., Kawka, M. and Jaszczak, K. (2012) Studies on Resources of Genetic Diversity in Conservative Flocks of Geese Using Microsatellite DNA Polymorphic Markers. Molecular Biology Reports, 39, 5291- 
5297. http://dx.doi.org/10.1007/s11033-011-1327-8

[24] Eltanany, M., Philipp, U., Weigend, S. and Distl, O. (2011) Genetic Diversity of Ten Egyptian Chicken Strains Using 29 Microsatellite Markers. Animal Genetics, 42, 666-669. http://dx.doi.org/10.1111/j.1365-2052.2011.02185.x

[25] Mukesh and Sathyakumar, S. (2011) Eighteen Polymorphic Microsatellites for Domestic Pigeon Columba livia var. domestica Developed by Cross Species Amplification of Chicken Markers. Journal of Genetics, 90, 86-89.

[26] Santos, D.O., Moreira, L.R., Tonhati, H. and Caparroz, R. (2012) Isolation and Characterization of Ten Novel Microsatellite Loci in the Red-Winged Tinamou (Rhynchotusrufescens, Tinamiformes, Aves) and Cross-Amplification in Other Tinamous. Molecular Biology Reports, 39, 4837-4840. http://dx.doi.org/10.1007/s11033-011-1277-1

[27] Wang, H., Lou, X., Zhu, Q., Huang, Y., Zhou, L. and Zhang, B. (2011) Isolation and Characterization of Microsatellite DNA Markers for the Oriental White Stork, Ciconiaboyciana. Zoological Science, 28, 606-608. http://dx.doi.org/10.2108/zsj.28.606 